\title{
49.213
}

ORNU/CSD/TM-58

\section{Nuclear Criticality Assessment of Oak Ridge Research Fuet Element Storage}

\author{
J. T. Thomas
}


ORML/CSD/TM-58

Distribution Category

UC-46

Contract No. H-7405 eng 26

COMPUTER SCIEMCES DIVISION

\section{MULLER CRITICALITY ASSESSMENT OF OAK RIDGE \\ RESEARCH FUEL ELEMENT STORAGE}

J. T. Thomas

Date Published - June 1978

NOTICE This document contains information of a preliminary nature. It is subject to revision or correction and therefore does not represent a final report.

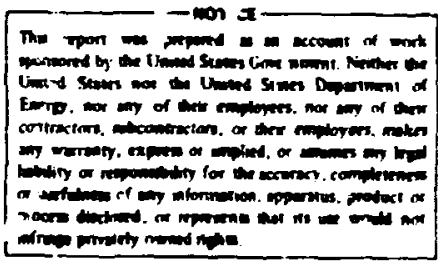

UNION CARBIDE CGRPORATION, NUCLEAR DIVISION nperating the

Oak Ridge Gaseolis Diffiusion Plant - Oak Ridge National Laboratory Oak Ridge Y-12 Plant - Paducah Gaseous Diffusion Plant for the

DEPARTMENT OF ENERGY 


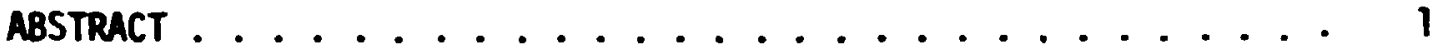

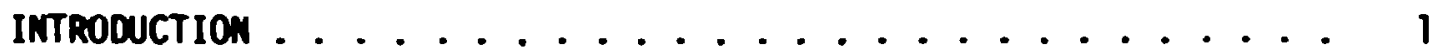

VALIDATION OF CALCULATIOHAL METHOD ............ 2

Table 1. Description of fuel plates and atom number densities . 4

CALCULATED AR.QANGEMENTS OF FUEL ELEMEMTS .......... 4

Table 2. Calculated k-eff for critical experiments with ORR and SPERT-D fuel elements ............... 5

Fig. 1. ORR fuel storage rack .............. 6

Table 3. Calculated neutron multiplication of various fuel elements in storage related configurations ........ 8

Table 4. Calculated neutron multiplication factor for submerged arrangements of ORR and of HFBR fuel elements .... 9

CONCLUSIONS ........................ 10

RECOMANDATIONS ........................ 10

REFERENCES .......................... 11 


\title{
MICLEAR CRITICAL ITY ASSESSMENT OF OAK RIDGE
}

\author{
RESEARCH FUEL ELEMENT STORAGE
}

\author{
J. T. Thomas
}

\section{ABSTRACT}

Spent and partially spent Oak Ridge Research Reactor (ORR) fuel elements are retained in the storage section of the ORR pool facility. Determination of a maximum expected neutron multiplication factor for the storage area is accomplished by a validated calculational method. The KEMO Monte Carlo code and the Hansen-Roach 16-group neutron cross section sets were validated by calculations of critical experiments performed with early ORR fue' elements and with SPERT-D fuel elenents. Calculations of various fuel elenent arrangements are presented which confirm the subcriticality previously inferred from critical experiments and indicate the $k_{e f f}$ would not exceed 0.85 , were the storage arez to be filled to capacity with storage racks containing elements with the fissionable material loading increased to $350 \mathrm{~g}$ of $235 \mathrm{~J}$.

\section{INTRODUCTICN}

During the life cycle of a fuel element in typical operations of the ORR reactor, the element may spend several extended periods in storage. In addition, storage space i- allocated to comp?etely spent fuel elements which remain in storage to permit sufficient radioactive decay and to accumulate a fuel element shipment lot. These activities with elements outside the reactor core must be conducted in a manner that assures the subcriticality of all operations.

The criticality safety of present procedures was established on the basis of critical experiments performed with ORR fuel elements prior to 1958. Consideration is being given to increasing the fissionable material loading of the elements. It is an appropriate time to reconfirm the subcriticality of operations and $t()$ estimate the keff that may be expected from the proposed higher material loadings. 
The variation in burnup and fuel element rotation implies the determination of subcriticality for any specific configuration would be singularly complex and not generally applicable. A conservative estimate of a maximan value of $k_{\text {eff }}$ would result from the assimption of fresh elements in the analysis. The evaluation is conductec by a validated calculational method.

\section{VALIDATION OF CAL CULATIOMAL METHOD}

Critical experiments with ORR and Bulk Shieiding Reactor (BSR) fuel elements were performed at the Oak Ridge Critical Experiments Facility (ORCEF), and reporied ${ }^{1}$ in 1958. A series of measurements established that a minimum of 15 elements containing $168 \mathrm{~g}^{235} \mathrm{U}$ each in a $4 \times 4$ matrix with a corner position vacant would be critical if the spacing between elements were $0.508 \mathrm{~cm}(0.2 \mathrm{in.})$. Other measurements used 12 of the $168 \mathrm{~g}$ elements with four other elements, having a $140 \mathrm{~g} 235 \mathrm{U}$ loading, in two different arrangements of a $4 \times 4$ matrix with zero spacing between elements. Critical experiments with the SPERT-D fuel elements were also conducted at the ORCEF and reported ${ }^{2}$ in $3: 165$. These elements contained $306.5 \mathrm{~g} 235 \mathrm{U}$. The SPERT-D plates have $57 \%$ more ${ }^{235 \mathrm{U}}$ than the ORR plates and both were fabricated with a uranium-aluminum alloy* core clad with aluminum. There are 19 plates in the ORR element. and 22 in the SPERT-D element. It is notable that the minimum critical mass is observed for the ORR $168 \mathrm{~g} 235 \mathrm{U}$ elements, al though fewer SPERT-D elements are required for criticality.

*Current operations at ORR use an oxide of uranium with aluminut. in place of the metal alloy. 
The ORR fuel elements are fabricated with curved plates. The two outer plates of an element are thicker $(0.165 \mathrm{~cm})$ than the 17 interior plates $(0.127 \mathrm{~cm})$. The element is described in the code as having flat plates. This is not a significant perturbation as the spacing between plates and between adjacent fuel elements is preserved. The dimensions of the fuel region in the plates and the atom number densities are given in Table 1. The experiments were calculated with the KENO Monte Carlo ${ }^{3}$ code using the Hansen-Roach ${ }^{4}$ 16-group neutron cross section sets. The arrangement of the fuel elements and the calculated keff's of the selected experiments are presented in Tabie 2. The second and third entries of the table show the effect of the relocation of the lighter (L) ORR elements. Criticality was achieved then the lighter elements were located symmetrically positioned at the outer boundaries of the array. Subcriticality resulted when the lighter elements occupied the central region of the array. These experiments are a significant test of the geometry description of the fuel elements in the code and of the cross section set used.

The influence of cross section set selection on the calculated $k_{\text {eff }}$ was explored by repeating the calculations of Table 2 using the Bonami option for cross section treatment in the AMPX system. 5 The results of these tests suggest that the normil procedure for dfterminirig cross section sets to be used, i.e., on the basis of scattering potential, $\sigma_{p}$, could result in at most a negative bias of 0.02 in $k_{e f f}$ with an uncertainty of $+1 \sigma$. This implies that systems calculated to have a $k_{\text {eff }}$ of 0.98 should be regarded as having a potential for criticality. 
Table 1. Dessiption of fuel plates and atom number densities

\begin{tabular}{|c|c|c|c|}
\hline Element & $\underline{\text { ORR }}$ & $\underline{\text { ORR }}$ & SPERT -D \\
\hline z3su per element, $g$ & 168 & 140 & 306.5 \\
\hline No. of plates & 19 & 19 & 22 \\
\hline \multicolumn{4}{|c|}{ Fuel Resion Dimensions, ca } \\
\hline width & \multicolumn{2}{|c|}{6.2865} & 6.2332 \\
\hline length & \multicolumn{2}{|c|}{59.8348} & 60.9600 \\
\hline thickness & \multicolumn{2}{|c|}{0.0698} & 0.0508 \\
\hline \multicolumn{4}{|c|}{ Atom Densities $\left(\times 10^{-2 n}\right)$} \\
\hline 23su & $8.61079-4$ & $7.18747-4$ & $1.84954-3$ \\
\hline 2340 & $6.22380-5$ & $5.19507-5$ & $1.33875-4$ \\
\hline 2'A1 & $4.14310-2$ & $4.21440-2$ & $5.535 ; 6-2$ \\
\hline \multicolumn{4}{|c|}{ Plate D+mensions, $\mathrm{cm}$} \\
\hline wioth & \multicolumn{2}{|c|}{7.117008} & 6.3682 \\
\hline length & \multicolumn{2}{|c|}{62.5475} & 63.3175 \\
\hline thickness & \multicolumn{2}{|c|}{0.127} & 0.1524 \\
\hline
\end{tabular}

\section{CALCULATED ARRANGEMENTS \\ OF FUEL ELEMENTS}

A typical storage rack is shown in Fig. 1. There are three rows of 10 elements each, and these are separated by at least $15.2 \mathrm{~cm}$ of water. The region betkeen rows within the rack is not accessible to elements. The guardrail and supporting gussets on the lateral surfaces maintain a $30 \mathrm{~cm}$ separation between elements in different storage racks. The dimensions of a fuel element storage position are $8.7 \times 8.7 \times 91.4 \mathrm{~cm}$. The rack is fabricated of aluminum, and the partitions defining compartments are $0.32 \mathrm{~cm}$ thick. The surface separation of adjacent elements in a row may vary from 0.32 to about $1.2 \mathrm{~cm}$. 
Table 2. Calculated k-eff for critical experiments with ORR and SPERT-D fuel elements.

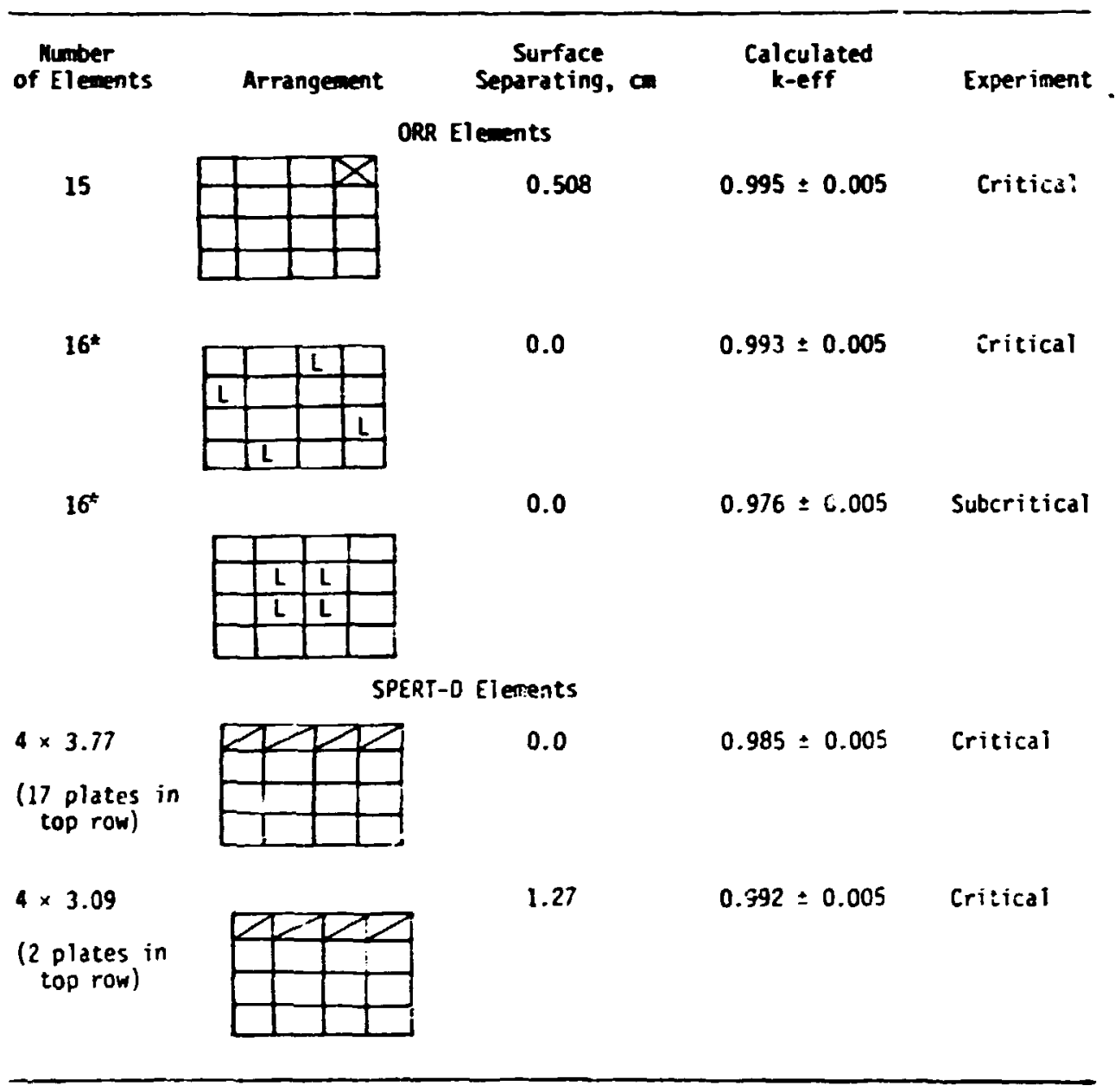

"Blank locations designate elements with 168 g $235 \mathrm{U}$; "L" in location designates $140 \mathrm{~g}$ ij $\mathrm{U}$ elements. 


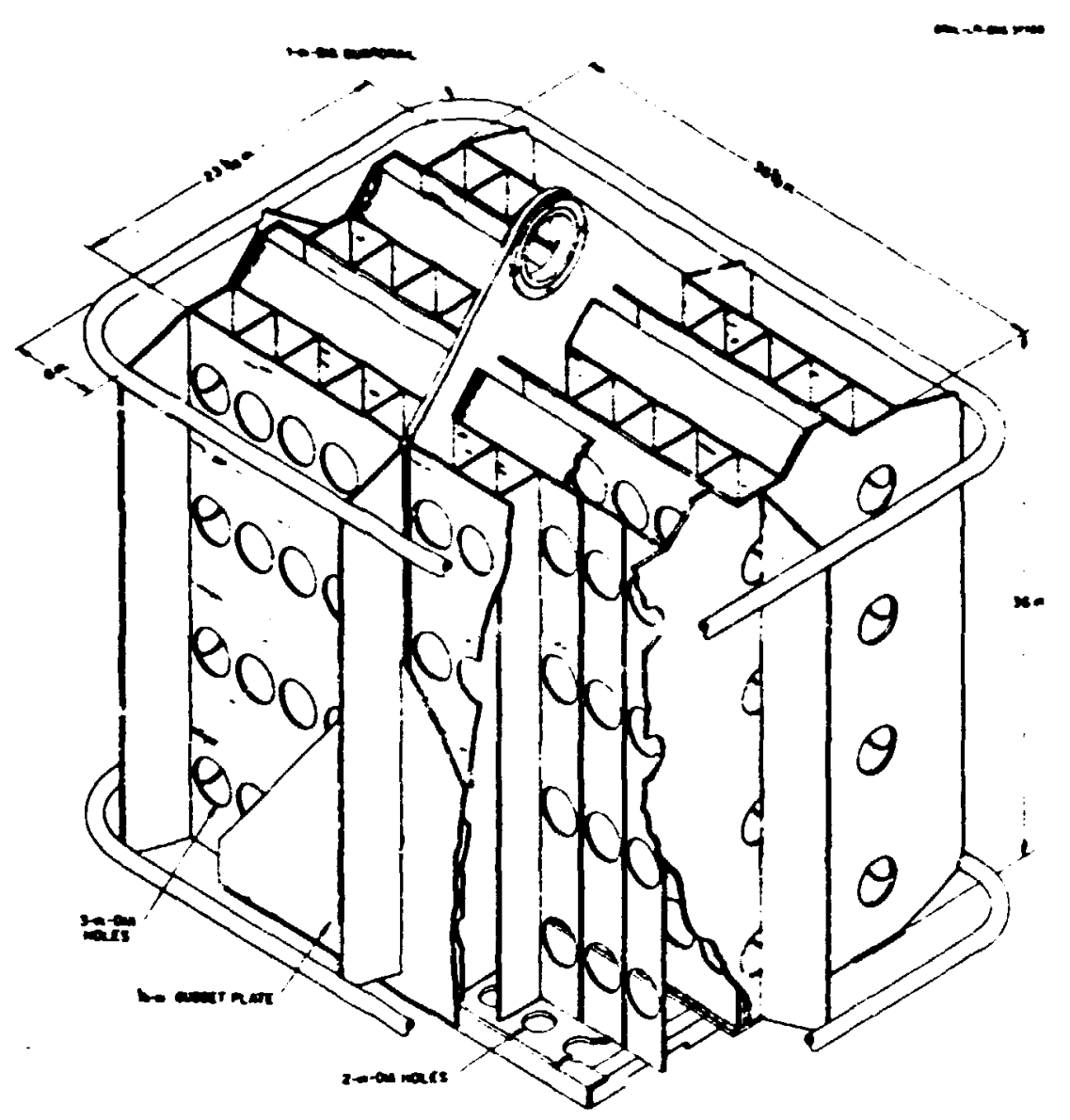

Fig. 1. ORR fuel storage rack.

A detailed description of a single rack having SFERT-D elements in the storage positions was calculated. The resulting $k_{\text {eff }}$ was $0.68+0.01$ and is the first entry of Table 3. The rack is not present in the remaining entries of the table. The second SPERT-D entry indicates a more reactive configuration when the aluminum of the rack is removed, and the rows are separated $15.2 \mathrm{~cm}$. The calculations of the ORR and the High Flux Beam Reactor (HFBR) elements, also shown in the second row of the table, imply 
a more reactive configuration than is achievable in the storage pool since these results overestimate the possib'e coupling of several storage racks available at the facility. The remaining entries of the table confirm the experimentally inferred subcriticality ${ }^{2}$ of two infinite rows of SPERT-D elements in contact and give comparative results for the ORR and HFBR elements in similar arrangements. Unlike the HFBR and SPERT-D fuel elements, the outer plates of the ORR fuel element are fuel bearing. This implies that additional reactivity is potentially available to the calculated ORR arrangements were the fuel elements to be slightly separat?d $(20.5-2 \mathrm{~cm})$. As the distance cetween fuel bearing plates in an array of HFBR elements when in contact is aboust $1.2 \mathrm{~cm}$, comparison with ORR calculations allows an estisiate of the expected $\Delta k_{\text {eff }}$.

Additional calculations of storage conditions were performed. These concerned the evaluation of the situation where an element is accidentally dropped between two storage racks. The expected increase in $k_{e f f}$ was evaluated from the calculations of two rows containing 10 each of $300 \mathrm{~g}$ $235 \mathrm{U}$ elements separated by $24 \mathrm{~cm}$. The elements in the rows were in contact. Calculations were performed with and without two $350 \mathrm{~g}^{235 \mathrm{U}}$ elements in contact and $c$ ?ntered in the space between rows. The keff's were $0.840 \pm 0.007$ and $0.795 \pm 0.009$, respectively, giving a $\Delta k_{\text {eff }}$ of about 0.05 . The calculations were repeated with the spacing between rows equal to $15.2 \mathrm{~cm}$ and resulted in a neutron multiplication factor of $0.953 \pm 0.010$ the two $350{ }^{235}{ }^{23}$ elements centered between the rows and $0.802 \pm 0.009$ without the extra elements. The $\Delta k_{\text {eff }}$ for this closer spacing is about 0.15 . These results suggest that a single fuel elenent 
between two storage racks located no closer than $30 \mathrm{~cm}$ would be about equal to the uncertainty in the calculations of Table 3 , i.e., about 0.01 in keff

\begin{tabular}{|c|c|c|c|c|c|c|}
\hline \multirow{3}{*}{$\begin{array}{l}\text { Total } \\
\text { Mumber of } \\
\text { Elements }\end{array}$} & \multirow{2}{*}{\multicolumn{2}{|c|}{$\begin{array}{l}\text { Arrangement thumer and } \\
\text { Surface separation. (cm) }\end{array}$}} & \multicolumn{3}{|c|}{ teff } & \multirow{3}{*}{$\frac{\text { HFER }}{3009}$} \\
\hline & & & \multirow{2}{*}{$\frac{\text { SPERT }-0}{306.59}$} & \multicolumn{2}{|c|}{ OPP. } & \\
\hline & in row & of row & & $300 \mathrm{~s}$ & $350 \Omega$ & \\
\hline $30^{2}$ & $10,1.2$ & 3.16 .3 & $0.67 \div 0.01$ & & & \\
\hline 30 & 10.0 & $3,15.2$ & $0.715+0.000$ & $0.71 \pm 0.01$ & $0.72 \pm 0.01$ & $0.80 \div 0.01$ \\
\hline- & -.0 & -.15 .2 & $0.78 \pm 0.01$ & $0.96 \pm 0.01$ & $0.89 \pm 0.01$ & $0.85 \pm 0.0 ?$ \\
\hline$=$ & -.0 & 2,0 & $0.974 \pm 0.008$ & $1.07+0.01$ & $1.00+0.01$ & $1.04 \pm 0.01$ \\
\hline - & -.0 & 2.1 .2 & $0.994 \div 0.008$ & & & \\
\hline - & -.0 & 2.7 .6 & $0.8882 \pm 0.007$ & & & \\
\hline- & -.16 .4 & $2,16.4$ & $\begin{array}{l}0.55 \pm 0.01 \\
\text { Element aes }\end{array}$ & ription & & \\
\hline & 5u per sle & & 306.5 & 300 & 350 & 350 \\
\hline & $\begin{array}{l}\text { Number of } \\
\text { element }\end{array}$ & Der & 22 & 19 & 19 & 18 \\
\hline & $\begin{array}{l}\text { Atom numb } \\
\text { core loa }\end{array}$ & ities of & $1.8495-3$ & $2.1182-3$ & $2.4713-3$ & $2.6141-3$ \\
\hline & & & 1.3388 .4 & $1.535 \%-4$ & $1.7916-4$ & $1.8832-4$ \\
\hline & & & & $6.0531-3$ & $7.0678-3$ & $7.4730-3$ \\
\hline & & & $5.5359-2$ & $5.1604-2$ & $5.0159-2$ & $5.2387-2$ \\
\hline & die Core U & n:, Cnir & & & & \\
\hline & Width & & 6.233 & & & 5.697 \\
\hline & Length & & 60.960 & 59. & & 58.054 \\
\hline & Thickness & & 0.0408 & & & 0.0579 \\
\hline & ter Plate & ons.,.? & & & & \\
\hline & widen & & 6.609 & & & 6.213 \\
\hline & Length & & 63.818 & 62 & & 60.324 \\
\hline & Thickness & & $0.1: 2$ & & & 0.128 \\
\hline
\end{tabular}

2Aluanimm rack included in this calculation only.

$b_{k}$ eff $=0.772 \pm 0.011$ when surface s3paration of elesents is $5.06 \mathrm{~cm}$ within anl between the two rows.

Finally, calculations were performed on arrangements typical of critical experiments with the ORR and HFBR fuel elements. These are presented in Table 4. 
These caiculations are consistent with the results of Table 3 and provide further insight to the nuclear criticality safety assessment of higher $235 \mathrm{U}$ loaded ORR elements.

Table 4. Calculated neutron multiplication factor for submerged arangements of ORR and of HFBR fuel elements

Elemer:ts are in contact.

\begin{tabular}{|c|c|c|c|c|}
\hline \multirow{2}{*}{$\begin{array}{l}\text { Fuel } \\
\text { Number }\end{array}$} & \multirow{2}{*}{$\begin{array}{c}\text { Element } \\
\text { Arrangement }\end{array}$} & \multicolumn{3}{|c|}{$k_{\text {eff }}$} \\
\hline & & $300 \mathrm{~g}$ ORR & $350 \mathrm{~g}$ ORR & $350 \mathrm{~g}$ HFBR \\
\hline \multirow{3}{*}{16} & $x x x x$ & & & \\
\hline & $\begin{array}{l}x x x x \\
x x x x\end{array}$ & $1.138 \pm 0.008$ & $1.167 \pm 0.008$ & $1.132 \pm 0.008^{\mathrm{a}}$ \\
\hline & $x x x x$ & & & \\
\hline \multirow{3}{*}{12} & $x x x x$ & & & \\
\hline & $x x \times x$ & $1.040 \pm 0.007$ & $1.087 \pm 0.007$ & $1.054 \pm 0.010$ \\
\hline & & & & \\
\hline \multirow{3}{*}{10} & $x \ddot{n}$ & & & \\
\hline & $x x x x$ & $1.012 \pm 0.008^{\mathrm{D}}$ & $1.038 \pm 0.006^{c}$ & $1.007 \pm 0.007$ \\
\hline & $x x x x$ & & & \\
\hline \multirow{3}{*}{12} & $x x x x$ & & & \\
\hline & $\begin{array}{ll}x & x \\
x & x\end{array}$ & $0.922 \pm 0.009$ & $0.926 \pm 0.008$ & $0.908 \pm 0.005$ \\
\hline & $x \times x x$ & & & \\
\hline $\begin{array}{r}a_{k} \\
b_{R} \\
\text { of } \quad .01\end{array}$ & $\begin{array}{l}=0.844 \pm 0 \\
\text { cing centra } \\
0.007 \text {. }\end{array}$ & $\begin{array}{l}12 \text { when surface } \\
\text { two elements wi }\end{array}$ & $\begin{array}{l}\text { eparation of el } \\
350 \mathrm{~g} \text { ORR el em }\end{array}$ & $\begin{array}{l}\text { ents is } 5.99 \mathrm{~cm} \\
\text { ts gave k eff }\end{array}$ \\
\hline $\begin{array}{r}C_{R} \\
\text { of } 1.03\end{array}$ & $\begin{array}{l}\text { Icing centra } \\
0.007 \text {. }\end{array}$ & two elements wi & $300 \mathrm{~g}$ ORR el & $s$ gave $k_{\text {eff }}$ \\
\hline
\end{tabular}




\section{CONCLLISIONS}

A reasonable upper $l i m i t$ to an expected $k_{\text {eff }}$ for 5 t.orage operations at the ORR pool facility is $\mathbf{0 . 8 5}$. Under the present ORR element loading, a $k_{\text {eff }} \leq 0.75$ is a more probable value. These 1 imits are also appiicable to the incident where a fuel element is inadvertently placed or dropped between two storage racks. There is a sufficient margin of subcriticality in established procedures to adequately provide for the handing of fuel elenents with up to $350 \mathrm{~g} 235 \mathrm{U}$ loadings. No significant evidence appeared in the course of this study to suggest that elements of different loadings be segregated, although this may be dictated by other requirements.

\section{RECOMENDATIONS}

Since the present operational procedures are adequate and there was no suggestion that the risk of criticality is changed, no specific recommendations are necessary. 


\section{REFERENCES}

1. J. K. Fox and L. W. Gilley, Critical Experiments with Arrays of $O R R$ and BSR luel Elements, Meutron Physics Division Annual Progress Report for period ending September 1, 1958, ORNL-2609, Oak Ridge National Laboratory (1958).

2. E. B. Johnson and R. K. Reedy, Jr., Critical Experiments with SPERT'D Fuel Elements, ORNL/TM-1207, Oak Ridge National Laboratory (1965).

3. L. M. Petrie and N. F. Cross, KENO-IV: An Improved Morte Carlo Criticality Program. ORML-4938, Oak Ridge National Laboratory (1975).

4. G. E. Hansen and H. H. Roach, Six and Sixteon Group Cross Sections for Fast and Intermediate Critical Assemblies, LAMS-2543, Los Alamos Scientific Laboratory (1961).

5. N. M. Greene, et al., AMPX: A Modular Code System for Generating Coupled Multigroup Neutron-Garma iibraries from ENDF/B, ORNL/TM-3706, Dak Ridge National Laboratory (1976). 